\title{
REMOTE SENSING SIGNATURE OF THE MORRO DO OURO GOLD DEPOSIT, MINAS GERAIS, BRAZIL, USING REFLECTANCE SPECTROMETRY: APPLICATION TO MINERAL EXPLORATION USING SPACEBORNE MULTISPECTRAL SENSORS
}

\author{
PATRÍCIA S. SWALF ${ }^{1}$, ALVARO PENTEADO CRÓSTA ${ }^{2}$ \\ \& CARLOS ROBERTO DE SOUZA FILHO ${ }^{2}$
}

\begin{abstract}
Morro do Ouro, located near the town of Paracatu, Minas Gerais State, Brazil, is a world-class example of low-grade, hightonnage, black shale-hosted gold deposit. Available geologic data coupled with reflectance spectrometry data were used to establish the "remote sensing signature" of this type of deposit. Spectral classification techniques, usually employed with hyperspectral remote sensing data, were used to carry out spectro-lithological mapping of mineralized rocks, using a Landsat-5 TM scene covering the Morro do Ouro deposit and surrounding terrains. Reference spectra used for classification were obtained from field and laboratory measurements of selected samples from known gold occurrences in the area. The results show that all known mineralized zones in the study region are identifiable by the method, despite Landsat- $5 \mathrm{TM}$ spectral and spatial limitations, as well as the constraints imposed by the sub-tropical environment. The spectra of major lithologic types associated with Morro do Ouro type gold deposits were then modelled using the spectral resolution of Terra ASTER ((Advanced Spaceborne Thermal Emission and Reflection Radiometer), a newer generation spaceborne sensor developed for geologic applications that has higher spectral resolution than Landsat TM. A comparison of the spectra convolved to the spectral resolution of both sensors demonstrates the benefits that higher spectral resolution spaceborne sensors bring to mineral exploration and points out ASTER as a better choice than TM for gold exploration along the Brasília Fold Belt.
\end{abstract}

Keywords: remote sensing, reflectance spectroscopy, black shale-hosted gold deposits.

Resumo ASSINATURA POR SENSORIAMENTO REMOTO DO DEPÓSITO DE OURO DE MORRO AGUDO, MINAS GERAIS, COM EMPREGO DE ESPECTROMETRIA DE REFLECTANCIA: APLICAÇÃO DE SENSORES MULTIESPECTRAIS ESPACIAIS À EXPLORAÇÃO MINERAL A jazida de Morro do Ouro, localizada próxima à cidade de Paracatu, Estado de Minas Gerais, é um exemplo clássico de depósito aurífero de alto teor e baixa tonelagem associados a filitos carbonosos. Dados geológicos disponíveis, em conjunto com dados de espectrometria de reflectância, foram utilizados para estabelecer a "assinatura por sensoriamento remoto" deste tipo de depósito. Técnicas de classificação espectral desenvolvidas para dados hiperespectrais foram empregadas no mapeamento espectro-litológico das rochas mineralizadas em uma imagem Landsat-5 TM que abrange o depósito de Morro do Ouro e áreas adjacentes. Dados espectrais de referencia utilizados no processo de classificação foram obtidos a partir de medidas de espectrometria de reflectância obtidos no campo e em laboratório, usando amostras selecionadas relacionadas às ocorrências auríferas conhecidas na área. Os resultados mostram que todas as zonas mineralizadas conhecidas na área de estudo são positivamente identificadas pelo método, apesar da limitada resolução espectral e também espacial do Landsat-5 TM e das limitações impostas pelas condições típicas de ambientes sub-tropicais. Os dados espectrais dos principais tipos litológicos associados ao depósito aurífero de Morro do Ouro foram então modelados usando a resolução espectral do Terra ASTER (Advanced Spaceborne Thermal Emission and Reflection Radiometer), u sensor orbital de geração mais recente e de maior resolução espectral do que o Landsat TM, desenvolvido especialmente para aplicações geológicas. Uma comparação dos espectros transformados para as resoluções de ambos os sensores demonstra os benefícios dos sensores de maior resolução espectral para as atividades de exploração mineral, indicando o ASTER como uma opção superior ao TM para a busca de mineralizações semelhantes na Faixa de Dobramentos Brasília.

Palavras-chave: sensoriamento remoto, espectroscopia de reflectancia, ouro, filitos carbonosos

INTRODUCTION Remote sensing is an important tool in mineral exploration aiding in the identification, mapping and assessment of different types of mineral deposits. Current sensors are capable of identifying spectral signatures which may indicate the presence of minerals formed by hydrothermal alteration processes associated with metallic deposits, such as gold, silver, copper and others. In addition, images acquired by these sensors can be used for the identification and interpretation of geologic structures, usually expressed as lineaments, which may also control the presence of ore deposits.

The various applications of remote sensing to mineral exploration were summarised by Sabine (1999). Most of the examples presented by this author, however, concentrate in areas of dry climate, with little emphasis on the environmental conditions found in areas of

1 - Rua Marquesa de Santos, 26/503, 22221-080 - Rio de Janeiro, Brasil, pswalf@hotmail.com

2 - Instituto de Geociências - Universidade Estadual de Campinas, Caixa Postal 6152, 13081-970 - Campinas, SP - Brasil, alvaro@ige.unicamp.br, beto@ige.unicamp.br 
tropical/sub-tropical climates, like most parts of Brazil.

The objective of this paper is to carry out spectral characterization of mineral assemblages occurring at the surface of the Morro do Ouro deposit (Crósta \& Rabelo 1993), in order to develop a model using remote sensing data for mineral exploration purposes along the Brasilia Fold Belt. The model was tested on a Landsat-5 TM scene, in order to assess its capability in defining potential targets for gold in the regions of Paracatu and Luziânia towns, in central Brazil.

GEOLOGIC AND PHYSIOGRAPHIC ASPECTS The study area is located within the Brasília Fold Belt, at the west margin of the São Francisco Craton (Fig.1), comprising the region located between the cities of Luziânia (GO) and Paracatu (MG). It includes Mesoproterozoic carbonaceous and siliciclastic metasediments of the Paracatu Formation (Fig.2) that host several gold occurrences, including the world class Morro do Ouro deposit.

Several of the gold occurrences in this portion of the Brasília Belt have been studied by Hagemann $(1988,1989)$, Hagemann et al. $(1988,1992)$ and Silva $(1991,1996)$. These authors pointed out the control of the gold deposits by low angle faults, related to a collision process during the Brasiliano orogeny (600-790 Ma). They also showed the close relationship between gold and carbonaceous matter present in the host rocks (carbonaceous phyllites, formed by low-grade metamorphism of black shales). Gold is found in its free form, disseminated in the phyllites or re-concentrated in deformed quartz veins. The metal also occurs associated with sulfides scattered within metamorphic/ hydrothermal assemblages. Relatively higher grades are found at the surface, in the ferruginous duricrusts typically formed under the environmental and physiographic conditions of the region.

Due to its genetic singularities, a proper type of ore deposit has been proposed by Silva (1996) for the gold occurrences in this region: Morro do Ouro-type gold deposit - MOTD. These occurrences are concentrated mainly in two regions, located at the vicinities of the towns of Paracatu and Luziânia respectively.

Bedrock exposure is quite limited in this region, due to intense weathering typical of sub-tropical environments, and there is a close relationship among rocks, soils, vegetation and surface morphology. Spectral signatures observed in remote sensing imagery are related almost entirely to vegetation and secondary, weathering-related, mineralogy of soils and rocks.

MATERIALS AND METHODS Spectral measurements were made in the field and laboratory using a FieldSpec-FR instrument (ASD, Inc.) operating in the visible and infrared regions, between 0.35 and $2.50 \mu \mathrm{m}$. Remote sensing data comprised a Landsat-5 TM scene (path 220 / row 072 WRS), acquired during the dry season (August 30, 1998). Preprocessing included atmospheric correction and conversion of DN values into reflectance, allowing the comparison of pixel reflectance values to reflectance values measured at the surface. The $5 \mathrm{~S}$ radiative transfer model was used for the conversion (Tanré et al. 1990). The image was geo-referenced to UTM map coordinates, using the nearest-neighbour resampling method.

Data analysis Around one hundred samples of geologic materials from the regions of Paracatu and Luziânia were collected, including soils and rocks associated with the gold deposits and their host rocks and hydrothermal quartz veins. Petrographic descriptions and spectral analysis were made, to characterize mineral paragenesis and establish the spectral signatures of the carbonaceous sericite-phyllites that host the mineralization, of the soils which result from supergene processes acting over them (chemical weathering) and of the hydrothermal alteration products.

Samples from three different types of geologic materials associated with gold occurrences were selected for classification purposes. They included, respectivelly, Morro do Ouro ore, Fazenda Lavras ore (a smaller gold mine located $12 \mathrm{~km}$ to NNW of Morro do Ouro) and ferruginous laterite duricrust representing the original cover of the mineralized areas.

Sample spectra obtained using the FieldSpec-FR were analyzed using a spectral classification program (SIMIS - SpectrometerIndependent Mineral Identification Software-Mackin, 1999). The program examines the spectra and, using a reference mineral spectral library, identifies constituent minerals based on diagnostic absorption features. Minerals from the USGS Digital Spectral Library were used as reference (endmembers) for classification of the samples. The location of samples in the geo-referenced Landsat-5/TM scene was done using GPS coordinates of the collection points.

Digital image processing Landsat-5 TM data were processed using spectral classification techniques, based on the spectral signatures of the three types of samples described above. Classification techniques were used to map different lithologies, focusing on the carbonaceous phyllites of the Morro do Ouro Member, the unit of the Paracatu Formation that hosts the homonymous gold deposit. The spectra of samples were convolved to the spectral resolution of TM and used as endmembers for classification of the entire Landsat-5 scene. Two techniques were used for this purpose: Spectral Angle Mapper (SAM) and Spectral Feature Fitting (SFF) (Crósta et al, 1998, Kruse et al, 1993, Research Systems International, 1999).

RESULTS Spectral analysis of samples MORRODOOURO ORE Weathering of the carbonaceous phyllites that host MOTD removes the carbonaceous matter, changing their original dark grey color into whitish grey (Meneses et al., 2001). The removal of carbonaceous matter also affects the spectral signatures: in unweathered phyllites, carbonaceous matter obliterates spectral features of the other rock-forming minerals, whereas in the weathered materials these features are much better depicted in the spectral curves.

The spectrum of the weathered phyllites (MOC) shows diagnostic features in the SWIR portion of the spectrum, with secondary features in the VNIR, denoting the predominance of hydroxylbearing minerals over iron oxides and hydroxides (Fig.3). Absorption features due to electronic processes can be seen in the VNIR, centered at $0.505,0.654$ and $0.962 \mu \mathrm{m}$. The first feature is less intense and it is related to $\mathrm{Fe}^{+2}$ transition processes (Hunt \& Ashley 1979). The other two features are more pronounced. In the SWIR, the strongest features are located at 1.412, 1.934 and $2.204 \mu \mathrm{m}$, with secondary features in 2.347 and $2.450 \mu \mathrm{m}$. Mineral analysis by the SIMIS software indicates the presence of muscovite, illite, goethite, a mixture of kaolinite-smectite and montmorillonite.

LATERITES Prior to the opening of the pit of the Morro do Ouro mine, the area was covered by a ferruginous lateritic duricrust, which represented the superficial expression of the MOTD. Spectral characterization of these laterites is therefore important in order to test the application of remote sensing data for detecting this 

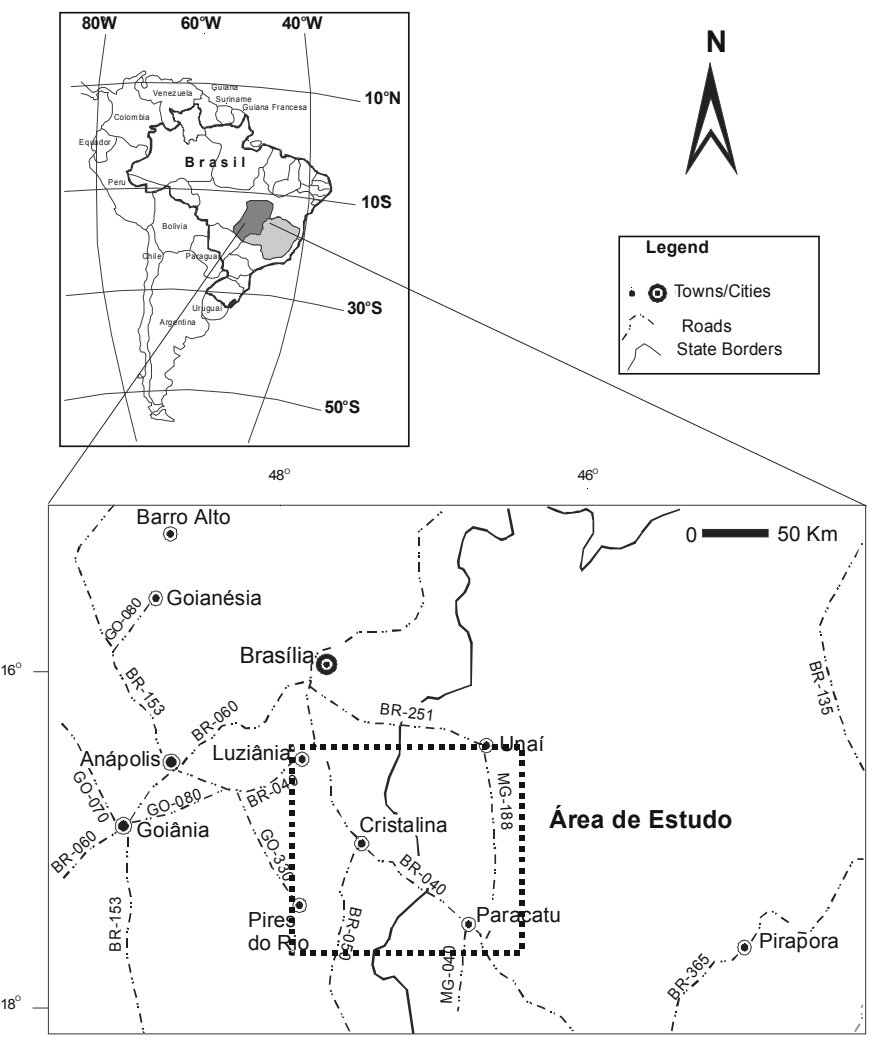

Figure 1 - Location of the study area. type of deposits in areas of tropical/subtropical climates. The samples of the laterites show reddish to brown colors and nodular texture.

Spectral features due to ferric iron are well expressed in the spectral curves of the laterite samples (Fig.4). These features include the overall decrease in reflectance values from 0.60 to 0.40 $\mu \mathrm{m}$ due to charge transfer phenomena, the crystal field shoulder at $0.535 \mu \mathrm{m}$ and a strong absorption feature at $0.954 \mu \mathrm{m}$.

In the SWIR region, absorption bands appear at 1.414, 1.784, 1.934 and $2.209 \mu \mathrm{m}$. Most of these features are due to vibrational processes involving the $\mathrm{OH}^{-}$ion. The absorption band at $1.784 \mu \mathrm{m}$ is a minor feature and can be due to a combined effect of fundamental stretch and the first overtone of the Al-O-H bond denoting the presence of smaller amounts of jarosite (Hunt \& Salisbury 1970). Results from the SIMIS software indicate the presence of hematite, goethite, smectite and montmorillonite.

FAZENDA LAVRAS ORE The ore is hosted by light-brown to grey sericite-phyllites, with the foliation marked by quartz layers. Deformed quartz veins (boudins) are less common in this deposit in comparison with the Morro do Ouro deposit. Spectral measurements were made in samples from the veins and from the weathered phyllites.

The spectrum from the vein (FL_vein in Fig. 5) shows distinctive absorption features in the SWIR, at 1.412, 2.202, 2.341 and 2.431 $\mu \mathrm{m}$, typical of hydroxyl-bearing (Al-OH) minerals. Secondary features due to ferric iron minerals are less pronounced in the VNIR, centered at $0.425,0.485,0.670$ and $0.924 \mu \mathrm{m}$. The FL_vein spectrum, found in several of the vein samples analyzed, represents the mineralogy of the phyllic alteration that affects the rocks of the
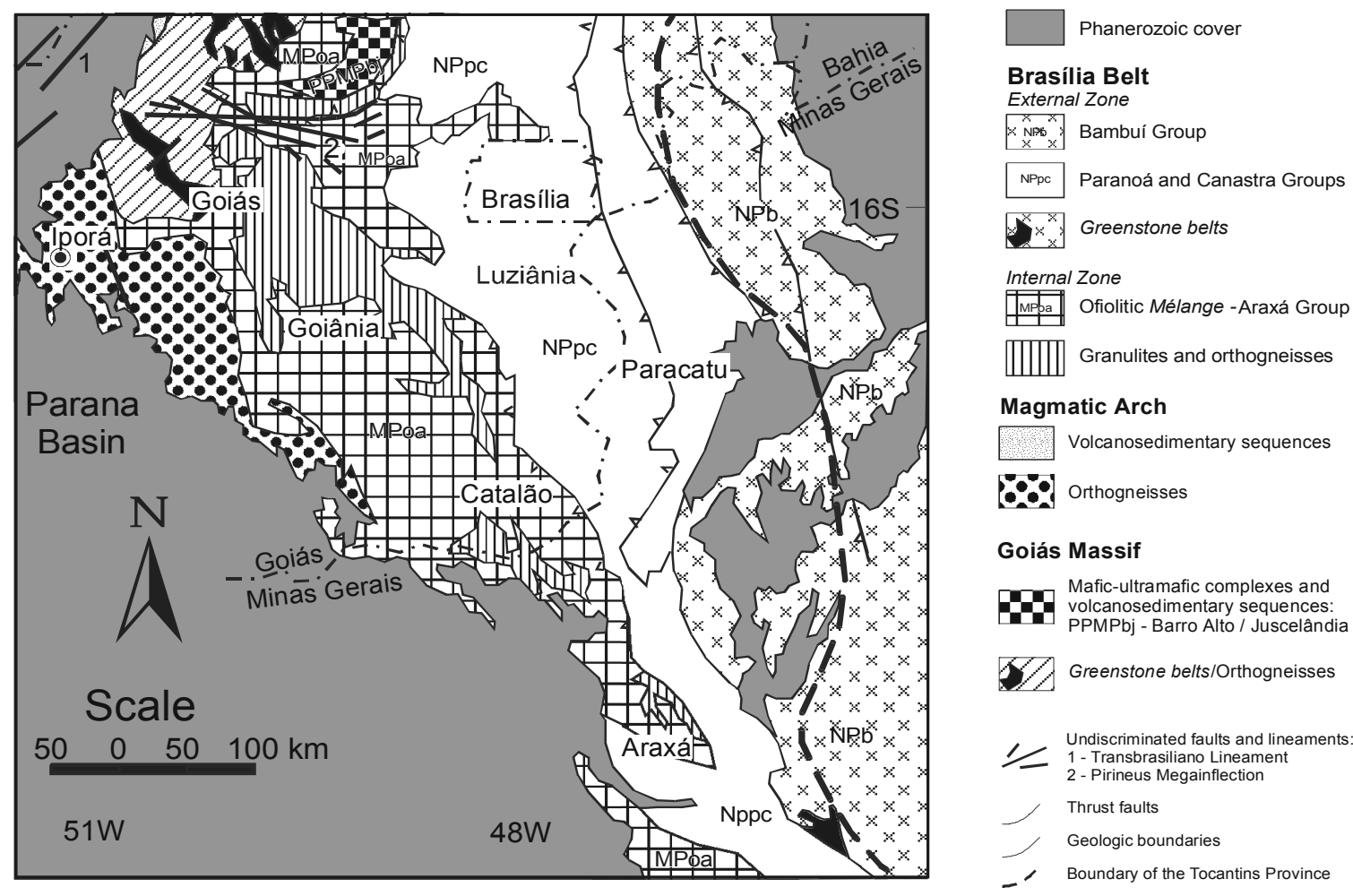

State boundaries

Figure 2 - Regional geology of the Brasilia Fold Belt, showing the location of the study area and the Morro do Ouro gold deposit. 


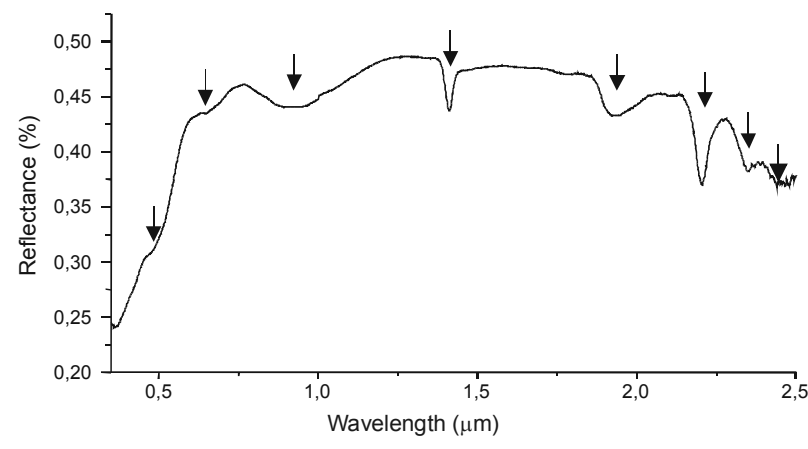

Figure 3 - Reflectance spectrum of gold-bearing weathered phyllite (MOC) from Morro do Ouro. Arrows indicate the location of main mineral absorption features mentioned in the text.

MOTD. Results from SIMIS indicate the presence of muscovite, illite, montmorillonite and jarosite. A broad band positioned at 1.9 $\mu \mathrm{m}$ indicates the presence of water.

Spectra from the weathered phyllites (FL_rock in Fig. 5), collected at the surface of the mine, show typical features due to ferric iron oxides/hydroxides in the VNIR, as well as less pronounced hydroxyl-bearing mineral features in the SWIR. Absorption bands centered at 0.67 and 0.924 show the presence of goethite, probably originated from weathered sulfides, as well as limonite. In the SWIR, the bands centered at 1.415, 2.204, 2.261 and $2.4111 \mu \mathrm{m}$ indicate the presence of illite.

Spectral classification of Landsat TM In order to classify the Landsat-5 TM image using hyperspectral classification techniques, it was necessary to choose the mineral endmembers to which the spectral signature of image pixels were to be compared to. These mineral endmembers were chosen amongst the spectra representing of the samples associated with MOTD. Initial tests carried out using a higher number of endmembers produced ambiguities and decreased the accuracy of the classification results (Swalf, 2000). Thus, a optimum number of three endmembers was chosen for the classification. These endmembers included weathered phyllite from Morro do Ouro (MOC), laterite, and weathered phyllite from Fazenda Lavras (FL_rock).

The spectra from Morro do Ouro and from Fazenda Lavras, after being convolved to the spectral resolution of Landsat-5 TM, are quite similar. The separation of these two classes was therefore used to assess the efficiency of the classifier. The areas where the respective samples were collected were used as control points for ground truthing.

SPECTRAL ANGLE MAPPER (SAM) The SAM classifier produces as results two types of images: a classification image and a separate set of spectral similarity gray level images, one image for each endmember employed. In this case, three spectral similarity images were produced. They were individually contrast-stretched and the pixels with higher values (higher similarity) were re-scaled to a dynamic range from 0 to 255 . Next, a RGB color composite of the three endmembers, allocating the endmember "laterite" to red, "MOC" to green and "FL rock" to blue, was produced and the results are presented in Figure 6.

Pixels with spectral signatures most similar to the MOC and FLrock endmembers only occur along the NNW-SSE structural trend of the Paracatu-Vazante fault (shown as green and blue pixels in

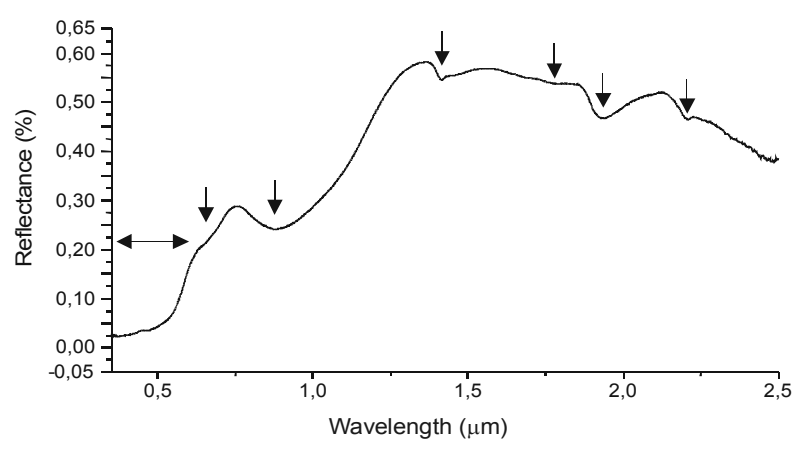

Figure 4 - Reflectance spectrum of capping laterite from Morro do Ouro-type deposit. Arrows indicate the location of main mineral absorption features mentioned in the text.

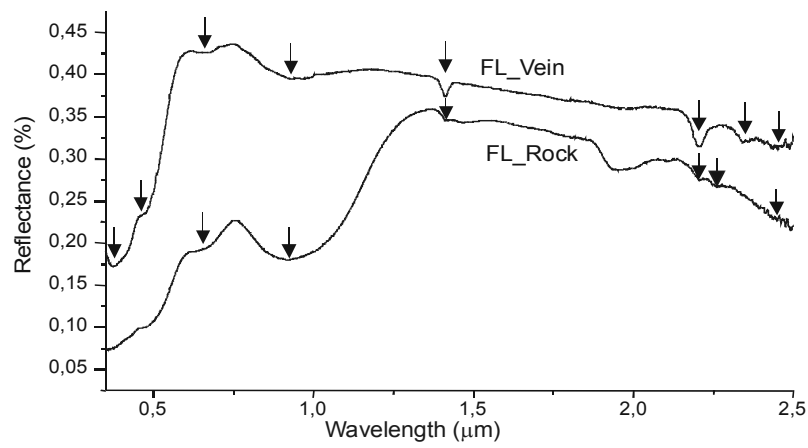

Figure 5 - Reflectance spectra of gold-bearing vein (FL-vein) and weathered phyllite (FL-rock) from Fazenda Lavras

Figure 6, respectively). This trend corresponds to the area of occurrence of the hydrothermally altered carbonaceous phyllites that host the MOTD.

The Morro do Ouro gold deposit and its surrounding areas are clearly shown in green (near the SSE corner the Figure 6), whereas the pixels classified as FL rock, in blue, occur around the Fazenda Lavras deposit and also away from it, but following the same NNWSSE trend. However, pixels classified as FL_rock are in smaller number than pixels classified as MOC and also more scattered away from the trend. The areas shown in cyan (light blue) colors indicated a mixture of spectral signatures from the MOC and FL rock endmembers and also follow the same directional trend, indicating the very likely occurrence at the surface of mixtures of both rock types (MOC and FL_rock). Finally, the pixels classified as laterite (in red) also show a pattern of occurrence away from the NNW-SSE trend, corresponding mostly to ploughed fields of red soils, concentrated in the NE and SW portions of Figure 6; they also occur in smaller areas along the same directional trend and around the known gold deposits.

A fairly high number of pixels appear to be classified by SAM as one of the three endmembers, although most of the pixels of the image were not classified at all. This possible exageration may be due to the simple nature of the classifier algorithm, which only depends of the threshold used for the spectral angle (in this case a value of 0.10 radians was used for the classification).

SPECTRAL FEATURE-FITTING The results from the SFF clas- 
sification, presented in Figure 7, show a dominance of pixels classified as the laterite endmember (in red). There are only a small amount of pixels classified as MOC (in green), mostly located right at the pit of the Morro do Ouro deposit, plus some concentrations of few pixels each, all following the NNW-SSE trend.

There are very few pixels that were classified by this method as FL rock (in blue), one of them being an area located in between the pits of the Morro do Ouro and Fazenda Lavras mines (at coordinates $298835 \mathrm{E}$ and $8106673 \mathrm{~N}$ ), representing a gold deposit similar to Fazenda Lavras that was still undisturbed by mining activities at the time of imaging. Although these overall results probably do not reflect precisely the areal extension of the FL_rock endmember, the fact that the classifier was able to identify pre- cisely the spectral signature of this endmember at this location testifies the potential of the method.

In comparison with the results provided by the SAM classifier, those by the SFF classifier appear to have over-classified the laterite endmember and under-classified the other two endmembers (MOC and FL_rock).

\section{SPECTRAL MODELLING OF HIGHER RESOLUTIONSEN-} SORS The classification results presented in the previous section demonstrated the constraints imposed by the limited spectral resolution of Landsat-5 TM in resolving subtle spectral differences of hydrothermally altered rocks of the Paracatu region.

In order to model the effects of a higher resolution multispectral
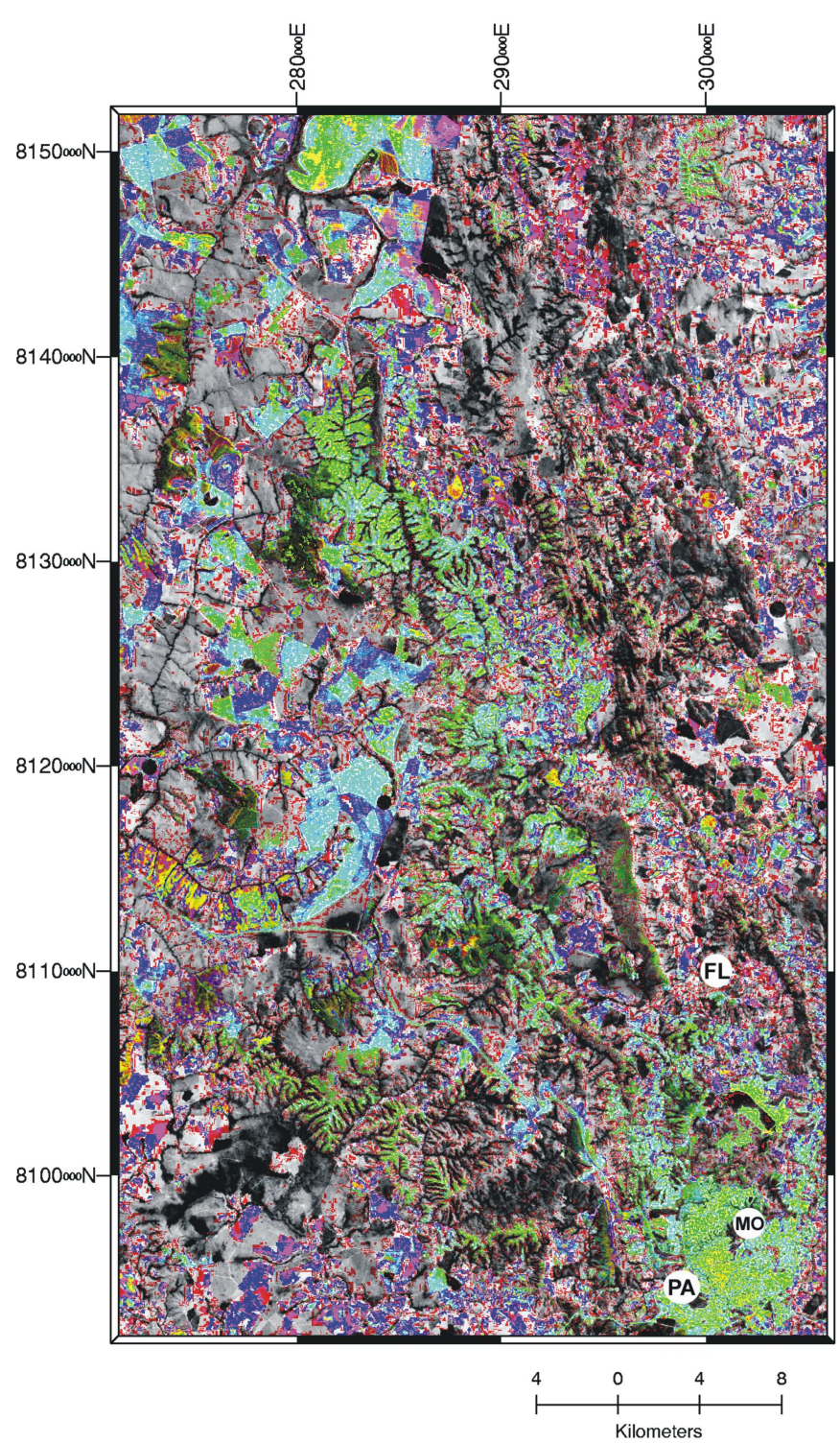

Figure 6 - Spectral classification of the Landsat-5-TM scene using $S A M$ classifier. Red = laterite endmember; Green $=M O C$ endmember; Blue $=F L$ rock endmember. Also shown the location of the Morro do Ouro (MO) and Fazenda Lavras (FL) gold deposits and the town of Paracatu (PA).

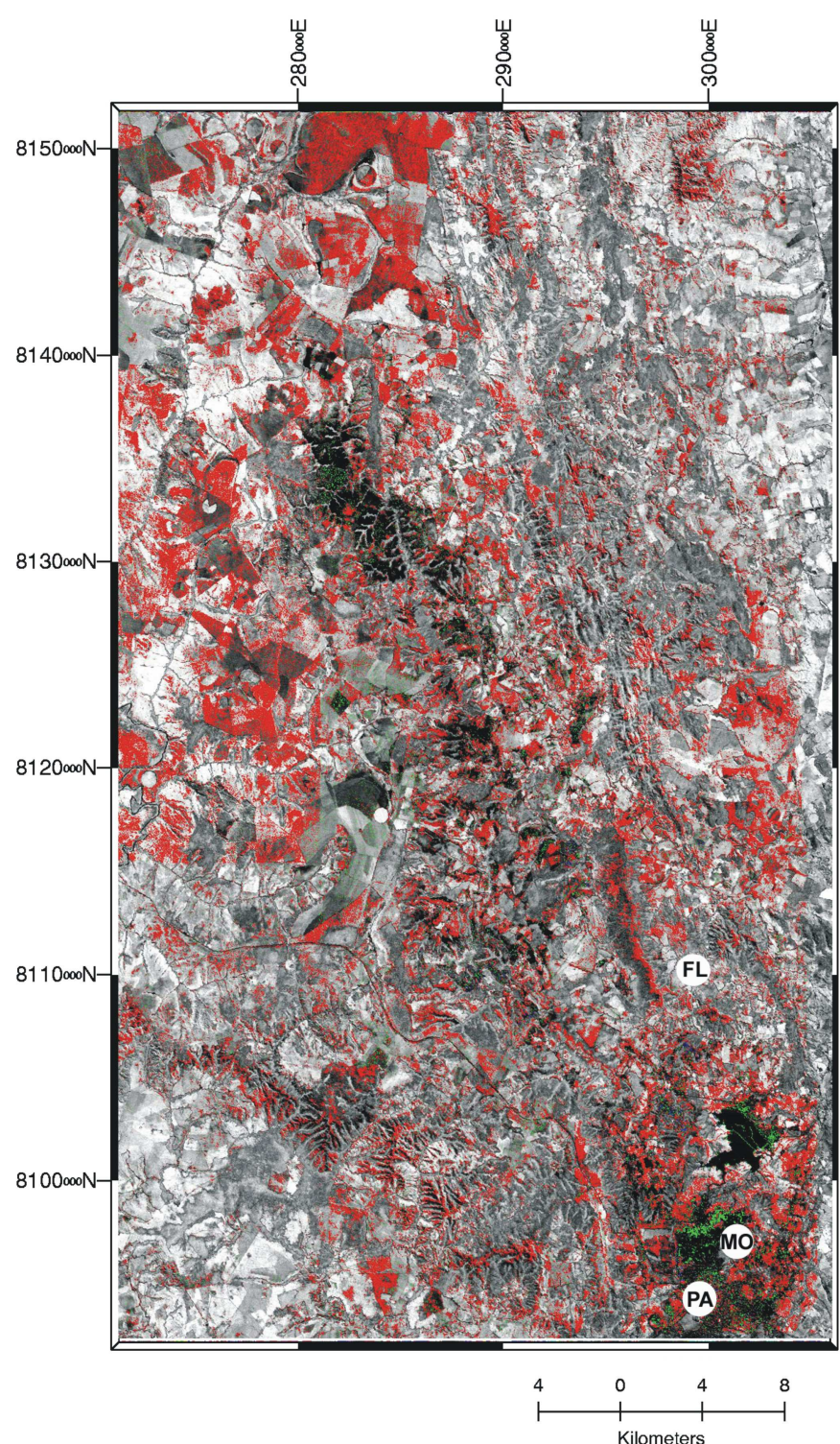

Figure 7 - Spectral classification of the Landsat-5-TM scene using SFF classifier. Red = laterite endmember; Green $=M O C$ endmember; Blue $=F L$ rock endmember. Also shown the location of the Morro do Ouro (MO) and Fazenda Lavras (FL) gold deposits and the town of Paracatu (PA). 
sensor for mapping different types of hydrothermally altered and laterized rocks related to MOTD, some of the spectra were convolved to ASTER (Advanced Spaceborne Thermal Emission and Reflection Radiometer) resolution, and to Landsat TM resolution. The convolution was done in ENVI, using the sensors response curves and a gaussian model based on the band centers and the FWHM (full width at half maximum) information for each sensor.

ASTER is a spaceborne sensor with improved spectral resolution compared to Landsat-5 TM, particularly in the SWIR, which became operational in late 1999 and is currently being used for mineral exploration worldwide. At the time this article was written, no real ASTER data were available yet for the Paracatu region.

Figure 8a shows the ASTER simulated spectra of carbonaceous phyllites that host gold occurrences in the study region (São Bartolomeu, Fazenda Lavras-FL_rock, Santa Maria and Paracatu), all showing some degree of hydrothermal alteration, the spectra of gold-bearing hydrothermally altered rocks (Morro do Ouro-MOC and Fazenda Lavras-FL-vein) and of laterite. Figure $8 \mathrm{~b}$ shows the same spectra, convolved to Landsat-5 TM resolution. It's worth noticing that, for the laterite, the spectral features due to ferric iron minerals in the VNIR are better resolved with Landsat TM simu- lated spectra. This is due to the fact that TM has an additional band in the blue portion of the electromagnetic spectrum, a region in which ferric iron minerals absorbs the energy. However, for the remaining samples (hydrothermally altered phyllites and vein), spectral features in the SWIR, diagnostic of hydrothermal alteration minerals, are much better resolved by ASTER than by TM. The fact that ASTER has five bands in the SWIR between 2.0 and $2.4 \mathrm{im}$, whereas TM has only one (band 7) makes it a much better choice for prospecting for Morro do Ouro-type gold deposits and also any other types of mineral deposits in which hydrothermal alteration plays an important role.

DISCUSSIONS AND CONCLUSIONS Morro do Ouro-type gold deposits show distinctive spectral signatures, related to cap materials (laterite) and to hydrothermally altered carbonaceous phyllites, as noted by Swalf (2000) and Meneses et al. (2001). These signatures were characterized by reflectance spectroscopy and the results were used to build a model that can be applied along the Brasília Fold Belt, to detect areas with potential interest for similar deposits using spectral information from remotely sensed imagery. The model was successfully tested using Landsat-5-TM
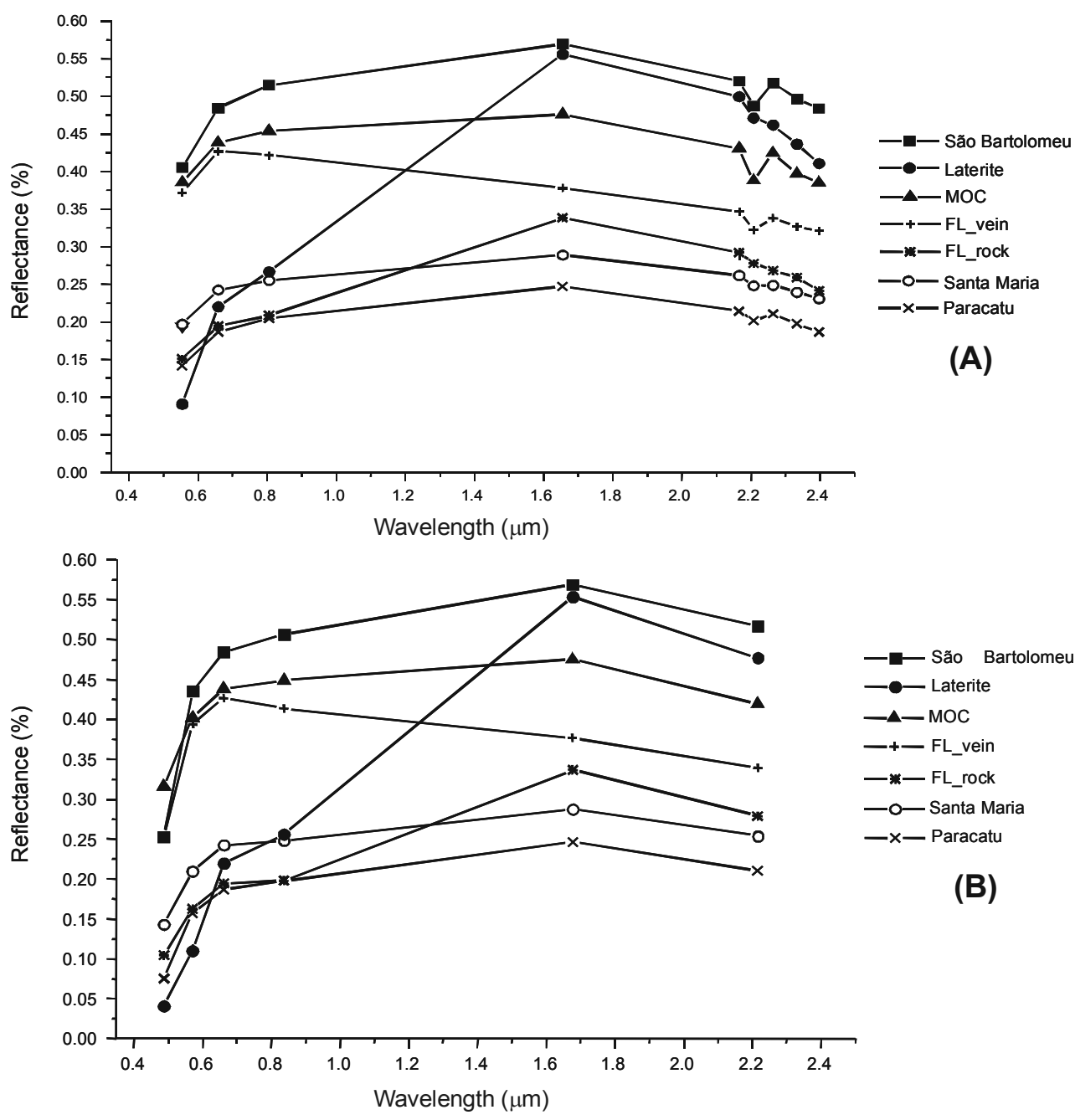

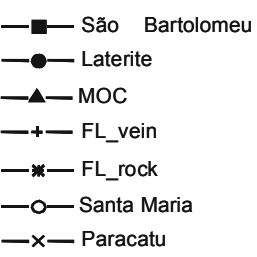

(B)

Figure 8 - Spectra of hydrothermally-altered phyllite, gold-bearing phyllite, gold-bearing veis and laterites, convolved to (a) ASTER and (b) Landsat-5-TM spectral resolution. 
imagery of the Morro do Ouro gold mine. Despite inherent spectral limitations of broad-band multispectral sensors such as TM, the classification results using sample spectra as endmembers and spectral classifiers such as SAM and SFF were accurate enough to detect all the known mineralized areas in the scene, plus some potentially interesting areas of similar signatures. A comparison of the results provided by both classification methods shows that SAM provided better spectral separation among the three endmembers used as spectral references, allowing to establish the spectral signatures of the main targets in the study area.

Although the use of broad-band multispectral sensors is more indicated for the identification of areas of likely occurrence of hydrothermal alteration, the results show that, by using specific spectral endmembers, it is possible to apply classification methods in order to identify specific mineral signatures with some degree of accuracy.

With the advent of higher resolution spaceborne sensors, such as ASTER, the possibilities can be extended beyond just identifying potentially interesting areas. The results obtained from modelling the spectra of hydrothermally altered rocks from MOTD to
ASTER spectral resolution demonstrate the capabilities for mapping different types of altered rocks with higher accuracy than by using Landsat-TM.

The results presented here also show the importance and advantages of the combined use of reflectance spectroscopy and multispectral spaceborne imagery in establishing the "remote sensing signature" of black-shale hosted gold deposits and its application in exploration activities in Brazil and elsewhere.

Acknowledgements P.A. Swalf was funded by Coordenação de Aperfeiçoamento de Pessoal de Nível Superior (CAPES). The authors acknowledge the support of Fundação de Amparo à Pesquisa no Estado de São Paulo (FAPESP), through grant 96/111392.A. P. Crósta and C. R. de Souza $F^{\circ}$ acknowledge the support from Conselho de Desenvolvimento Científico e Tecnológico (CNPq), through research grants 320.229/84 and 301.227/94, respectively. The authors are grateful to Rio Paracatu Mineração (RPM) and to $\mathrm{M}$. Batellochi for their support during field work. The anonymous reviewers also contributed to the improvement of the original manuscript.

\section{References}

Crósta A.P. \& Rabelo A. 1993. Assessing Landsat TM for hydrothermal alteration mapping in central-western Brazil. In: $9^{\text {th }}$ Thematic Conference on Geologic Remote Sensing, Pasadena, California. Proceedings, 1:1053-1061.

Crósta A.P., Sabine C., Taranik J.V. 1998. Hydrothermal alteration mapping at Bodie, California, using AVIRIS hyperspectral data. Rem. Sensing of Environment, 65:309-319.

Fuck R.A., Jardim de Sá E.F., Pimentel M.M., Dardenne M.A., PedrosaSoares A.C. 1993. As Faixas de Dobramentos Marginais do Cráton do São Francisco: Síntese dos Conhecimentos. In: J.M.L. Dominguez \& A. Misi (ed.) O Cráton do São Francisco. Salvador, SBG/SGM/CNPq. p. 161-185.

Hagemann S.G. 1988. The Structure, Petrology and Geochemistry of the gold-bearing Canastra Phyllites Near Luziânia-Goiás, Brazil, MSc. Dissertation, $156 \mathrm{p}$.

Hagemann S.G. 1989. The petrology and structural geology of the Proterozoic Canastra Group near Luziânia-Goiás, Brazil. Zbl. Geol. Palaeont. Teil. 5/6:887-901.

Hagemann S.G., Leonardos O.H., Rodrigues L., Walde D.H.G. 1988 The gold-bearing Canastra phyllites of Luziânia: a model of thinskinned thrust mineralization of the Brasilia Belt. Austral. Geol. Soc., 23:187-189.

Hagemann S. G., Brown P. E., Walde D. H. G. 1992. Thin-skinned thrust mineralization in the Brasilia fold belt: the example of the old Luziânia gold deposit. Mineral. Depos., 27:293-303.

Hunt G.R. \& Salisbury J.W. 1970. Visible and near-infrared spectra of minerals and rocks. I Silicate Minerals. Modern Geology, 1:283-300.

Hunt, G.R. \& Ashley, R.P. 1979. Spectra of Altered rocks in the visible and near infrared. Econ. Geol., 74:1613-1629.

Kruse F.A., Lefkoff A.B., Boardman J.W. 1993. The Spectral Image Processing System (SIPS) - interactive visualization and analysis of imaging spectrometer data. Rem. Sensing of Environment, 44:145163.

Mackin S. 1999. SIMIS-Spectrometer Independent Mineral Identification Software. User's Manual. 56 p.

Meneses P.R., Pontara R.C.P., Silva F.H.F., Madeira Neto J.C. 2001. Comportamento de reflectância espectral de filitos carbonosos mineralizados em ouro. Rev. Bras. Geoc., 31:83-88.

Research Systems International. 1999. ENVI-The Environment for Visualizing Images. User's Guide, 864 p.

Sabine C. 1999. Strategies for Mineral Exploration. In: A.N. Rencz (ed.) Remote Sensing for the Earth Sciences - Manual of Remote Sensing, 3rd Edition, v. 3. John Wiley/American Society for Photogrammetry and Remote Sensing.

Silva F.H.F. 1991. Enquadramento litoestratigráfico e estrutural do depósito de Ouro de Morro do Ouro, Paracatu - MG. Geosciences Institute, University of Brasília, Brasília, MSc. Dissertation, 151 p.

Silva F.H.F. 1996. Metalogênese do depósito do Morro do Ouro, Paracatu, $M G$. Geosciences Institute, University of Brasília, Brasília, Ph.D. Thesis, $337 \mathrm{p}$.

Swalf P.S. 2000. Modelo exploratório para depósitos auríferos do tipo Morro do Ouro com base em dados e técnicas de sensoriamento temoto. University of Campinas, Campinas, São Paulo, MSc. Dissertation, $118 \mathrm{p}$.

Tanré D., Deroo C., Herman M., Morcrette J.J., Perbos J., Deschamps P.Y. 1990. Apud Zullo Jr. J. 1996. Atmospheric correction of satellite images in a tropical region, Int. Archives of Photogrammetry and Remote Sensing, Viena, Austria, pp.831-834

Manuscrito SR-30

Recebido em 30 de setembro de 2002

Revisão dos autores em 06 de março de 2003 Revisão aceita em 21 de abril de 2003 